\title{
Growth performance, nutrient digestibility and intestinal morphology in weaned piglets fed fungal and bacterial fermented soya proteins*
}

\author{
Y.G. Kim, J.D. Lohakare and B.J. Chae ${ }^{1}$ \\ Division of Animal Resources, \\ Kangwon National University \\ Chunchon 200-701, Korea
}

(Received 21 October 2005; revised version 29 December 2005; accepted 12 April 2006)

\begin{abstract}
To elucidate the efficacy of fungal and bacterial fermented soya proteins (FSP) on piglet's performance, a total of 300 weaned piglets (Duroc $\times$ Yorkshire $\times$ Landrace, $23 \pm 3 \mathrm{~d}$ of age, 5.56 $\pm 1.21 \mathrm{~kg}$ initial BW) were allotted to 5 treatment diets comprising control, FSP-A $3 \%$, FSP-A $6 \%$, FSP-B 3\% and FSP-B 6\%, respectively. Fungus (Aspergillus oryzae), and fungus + bacteria (Aspergillus oryzae + Bacillus subtilis) were utilized for fermentation of soya proteins for FSP-A and FSP-B, respectively. There were 15 pigs per pen and 4 pens per treatment. Control diet contains $15 \%$ soyabean meal (SBM) and for the treatment diets SBM was replaced at 3 and $6 \%$ for each FSP-A and FSP-B, respectively. Experimental diets were fed from 0 to $14 \mathrm{~d}$ after weaning and then a common commercial diet was fed from 15 to $35 \mathrm{~d}$. At $14^{\text {th }} \mathrm{d}$ of experimental feeding, there were no significant differences in ADG, ADFI or feed to gain ratio between the bacterial and fungal fermented soya protein sources. For $15-35 \mathrm{~d}$ and overall period $(0-35 \mathrm{~d})$, the ADG was higher $(\mathrm{P}<0.05)$ in pigs fed FSP-B at $6 \%$ when compared with SBM. Higher $(\mathrm{P}<0.05)$ ADG was noted in pigs fed FSP-B diet when compared with FSP-A at both phases; and at higher level of supplementation only during overall phase. The apparent digestibility of $\mathrm{CP}, \mathrm{EE}, \mathrm{Ca}$ and $\mathrm{P}$ was higher in FSP-B diet than to FSPA that might have affected the ADG. Apparent digestibility of the amino acids were not different among the fermented protein sources but higher digestibility of some of the amino acids were noted at higher level of supplementation, irrespective of the source. Villous height and crypt depth were not affected by dietary treatments at ileal region. In

conclusion, the growth rate and digestibility of nutrients in weaned pigs fed FSP-B showed improvement than those fed SBM or FSP-A at higher level of supplementation.
\end{abstract}

KEY WORDS: piglets, growth rate, nutrient digestibility, fermented soya protein

\footnotetext{
* Partly supported by the Kangwon National University, Agricultural R\&D Promotion Center and Genebiotech Company Ltd., Seoul, Korea

${ }^{1}$ Corresponding author: e-mail: bjchae@kangwon.ac.kr
} 


\section{INTRODUCTION}

Soyabean meal (SBM) is an essential component in the feed formulation used for farm animals throughout the world. However, because of antigenic activity and anti-nutritional factors, young animals such as calves and piglets are sensitive to SBM and poor growth and digestive disorders are common when it is fed (Lalles, 1993).

In fact, milk products such as dried skim milk and dried whey and other animal protein sources like spray-dried plasma proteins and dried porcine soluble are typical feed ingredients in young pigs due to their high palatability and digestibility, but these are somewhat expensive. Therefore, specially processed soya products such as soya protein concentrate (SPC), HP300 and soya protein isolate (SPI) is used in the starter diets.

Refined soya proteins sources like FSP, a specially designed protein source prepared by fermentation and enzymatic degradation of dehulled soyabean meal has been reported to have a promising future in the diets of weanling piglets (Genebiotech Co. Ltd., Seoul, Korea, company brochure). The fermentation was carried out by using Aspergillus oryzae and Bacillus subtilis. The methodology is based on principle that microorganisms utilize carbohydrates and thereby the proteins are concentrated and since microbes are also protein in nature, it ultimately increases the protein content of the product after fermentation.

A. oryzae and B. subtilis were isolated from fermented soya (Meju). The ability of these isolated microbes was improved by mutation for enhance amylase production. The processing method contains soaking, increasing surface area, injection of microbes, fermentation at higher temperature and then drying. This increases the crude protein content to $53-57 \%$. The trypsin inhibitor, oligosaccharides like raffinose and stachyose in soyabean meal was removed during fungal and bacterial fermentation by protease and glucoamylase causing hydrolysis and the processed soya protein was developed (Kim, 2005). Recently, Min et al. (2004) reported that feeding processed soya protein to weanling pigs that has high proportion of small peptides increased growth performance, nutrient digestibility and apparent ileal digestibilities of DM, $\mathrm{N}$ and most amino acids.

There are no studies with respect to comparison of fermented soya protein sources in weaned pigs diet and its effect on performance, intestinal histometry, and apparent nutrient digestibility. Hence, the present study was conducted to evaluate and compare the effects of fermented soya protein sources on piglets performance, apparent digestibility of amino acids and ileal histometry in the weaned pigs fed until 14 days after weaning, and whether they further affect the growth performance fed a common diet for next 21 days. 


\section{MATERIAL AND METHODS}

The project underwent proper ethical standards and approved by Kangwon National University animal care and use committee. Three hundred weaned pigs of $23 \pm 3 \mathrm{~d}$ of age (Duroc $\times$ Yorkshire $\times$ Landrace) were allotted to five treatments with 4 replicates in each, comprising 15 pigs per pen of the same ancestry but mixed sex. The average body weight when weaned was $5.56 \pm 1.21 \mathrm{~kg}$. The pigs were housed in partially slotted and concrete floor pens with a pen size of 1.9 $\times 2.54 \mathrm{~m}$, with a self-feeder and nipple waterer to allow ad libitum access to feed and water. The main objective of the study was to compare fermented soya protein sources in weaned pigs diet. Hence the soya protein sources used were soyabean meal (SBM), fungal fermented soya proteins (FSP-A) at 3 and $6 \%$ level, and fungus + bacteria fermented soya protein (FSP-B) at 3 and $6 \%$, respectively. Iso-energy $(13.8 \mathrm{MJ} / \mathrm{kg})$ and iso-proteinous $(21 \% \mathrm{CP})$ diets were formulated and lysine content $(1.55 \%)$ was similar in all the diets.

In this experiment the high quality soya proteins were produced by fungal and bacterial fermentation, which was different and unique. The fermented soya proteins developed by this method had low antinutritional factors and it contained small peptides (data not shown). The microbial protease increases their crude proteins to 53-57\% and 25 kilodalton (kda) small peptides were produced (Kim, 2005).

All the diets meet or exceed the nutrient requirements as suggested by NRC (1998). These diets were fed for only 14 days (Phase I) in mash form, and then each group was fed the common commercial diet as crumbs during phase II (15-35 d). The composition of the starter diet (Phase-I, for 2 weeks) is presented in Table 1. The experiment was conducted for 5 weeks during which the body weights and feed intake were noted at the end of each phase of experimental feeding.

In order to study the effect of fermented soya protein sources on apparent nutrient digestibility, a digestibility trial was conducted using chromic oxide $(0.25 \%)$ as an indicator. The pigs were fed diets mixed with chromic oxide on day 7 and faecal samples were collected from day 11 to 14 during phase I and pooled. The faecal samples were dried in a forced-air drying oven at $60^{\circ} \mathrm{C}$ for $72 \mathrm{~h}$ and ground with a $1 \mathrm{~mm}$ mesh Wiley mill for chemical analysis.

To study the effect of diets on apparent ileal amino acid digestibilities, ileal villi height and crypt depth, representative pigs from each group ( 2 per replicate) reflecting average body weights were selected and killed by electrocution at 14 days of age. Immediately after slaughter the small intestine was excised. The ileal contents (chyme) were collected in sterilized plastic bottle in icebox and then brought to laboratory and freeze-dried until analysis for apparent ileal amino acid digestibility. The ileal region of small intestine was then immersed in $10 \%$ buffered formaline and then brought to laboratory for further studies. 
Table 1. Formula and calculated composition of experimental diets for feeding trial (day 0 to 14 )

\begin{tabular}{|c|c|c|c|c|c|}
\hline & \multirow{2}{*}{ Control } & \multicolumn{2}{|c|}{ FSP-A, $\%$} & \multicolumn{2}{|c|}{ FSP-B, \% } \\
\hline & & 3 & 6 & 3 & 6 \\
\hline \multicolumn{6}{|l|}{ Ingredient, \% } \\
\hline whey powder & 38.00 & 38.00 & 38.00 & 38.00 & 38.00 \\
\hline maize & 30.38 & 30.70 & 31.03 & 30.90 & 31.15 \\
\hline SDPP & 4.00 & 4.00 & 4.00 & 4.00 & 4.00 \\
\hline biscuit by-product & 4.00 & 4.00 & 4.00 & 4.00 & 4.00 \\
\hline SBM (48\%) & 15.00 & 12.00 & 9.00 & 12.00 & 9.00 \\
\hline FSP-A, B & 0.00 & 3.00 & 6.00 & 3.00 & 6.00 \\
\hline fish meal $(60 \%)$ & 3.81 & 3.40 & 2.99 & 3.18 & 2.87 \\
\hline animal fat & 2.00 & 2.00 & 2.00 & 2.00 & 2.00 \\
\hline L-lysine $\mathrm{HCl}(78 \%)$ & 0.32 & 0.34 & 0.35 & 0.34 & 0.34 \\
\hline DL-methionine $(100 \%)$ & 0.13 & 0.14 & 0.16 & 0.15 & 0.15 \\
\hline limestorne & 0.75 & 0.81 & 0.87 & 0.84 & 0.89 \\
\hline salt & 0.20 & 0.20 & 0.20 & 0.20 & 0.20 \\
\hline vitamins premix $^{1}$ & 0.30 & 0.30 & 0.30 & 0.30 & 0.30 \\
\hline minerals premix ${ }^{2}$ & 0.20 & 0.20 & 0.20 & 0.20 & 0.20 \\
\hline choline chloride $(25 \%)$ & 0.10 & 0.10 & 0.10 & 0.10 & 0.10 \\
\hline Apramycin & 0.15 & 0.15 & 0.15 & 0.15 & 0.15 \\
\hline Mecadox & 0.10 & 0.10 & 0.10 & 0.10 & 0.10 \\
\hline Sulfathiazol & 0.10 & 0.10 & 0.10 & 0.10 & 0.10 \\
\hline acidifier & 0.20 & 0.20 & 0.20 & 0.20 & 0.20 \\
\hline zinc oxide & 0.25 & 0.25 & 0.25 & 0.25 & 0.25 \\
\hline \multicolumn{6}{|l|}{ Calculated composition } \\
\hline $\mathrm{ME}, \mathrm{MJ} / \mathrm{kg}$ & 13.83 & 13.82 & 13.82 & 13.83 & 13.83 \\
\hline $\mathrm{CP}, \%$ & 21.00 & 21.00 & 21.00 & 21.00 & 21.16 \\
\hline lactose, $\%$ & 24.70 & 24.70 & 24.70 & 24.70 & 24.70 \\
\hline $\mathrm{Ca}, \%$ & 0.82 & 0.82 & 0.82 & 0.82 & 0.82 \\
\hline available $\mathrm{P}, \%$ & 0.41 & 0.41 & 0.40 & 0.40 & 0.40 \\
\hline Lys, \% & 1.55 & 1.55 & 1.55 & 1.55 & 1.55 \\
\hline Met+Cys, \% & 0.85 & 0.85 & 0.85 & 0.85 & 0.92 \\
\hline Thr, \% & 0.91 & 0.91 & 0.91 & 0.91 & 0.85 \\
\hline
\end{tabular}

${ }^{1}$ supplied per kg diet: vit. A 9600IU, vit. $\mathrm{D}_{3} 1800 \mathrm{IU}, \mathrm{mg}$ : vit. E 24, vit. B1 1.5, vit. B2 12, vit. B6 2.4, vit. B12 0.045 , vit. $\mathrm{K}_{3} 1.5$, pantothenic acid 24 , niacin 45 , biotin 0.09 , folic acid 0.75 , ethoxyquin 18 ${ }^{2}$ supplied per kg diet, mg: Fe 162, Cu 96, Zn 72, Mn 46.49, I 0.9, Co 0.9, Se 0.3

The small intestinal segment, especially at ileum, was rinsed with $0.4 \mathrm{M} \mathrm{KCL}$ and then cut in $2 \mathrm{~mm}^{2}$ small segments and submerged in a fixative solution $(0.1 \mathrm{M}$ collidine buffer, $\mathrm{pH}$ 7.3) containing, \%: glutaraldehyde 3, paraformaldehyde 2 and acrolein 1.5. Cross-sectional small intestine samples from the formalin preserved segments were fixed by standard paraffin embedding. Samples were sectioned at 6 $\mu \mathrm{m}$ and stained with azur A and eosine. Villous height and crypt depth were measured on the stained sections under microscope at 40x magnification equipped with an ocular micrometer. A minimum of 10 well-oriented intact villi was measured in duplicate specimens for each pig. Villous height was measured from the crypt base to the villous tip and all measurements (villous height and crypt depth) were made in 10-micrometer increments as mentioned by Cera et al. (1988). 
Proximate analyses of the experimental diets were carried out following the AOAC (1990) methods. Gross energy was measured by a bomb calorimeter (Model 1261, Parr Instrument Co., Molin, IL), and chromium with an automated spectrophotometer (Shimadzu, Japan) according to the procedure of Fenton and Fenton (1979). Following acid hydrolysis in $6 \mathrm{~N} \mathrm{HCL}$ at $105^{\circ} \mathrm{C}$ for $24 \mathrm{~h}$, amino acid concentrations were analysed by using a HPLC (Waters 486, USA). Sulphur containing amino acids was analysed after cold performic acid oxidation (Moore, 1963) overnight with subsequent hydrolysis.

Data collected was subjected to statistical analysis using GLM procedure of SAS (1985) by using statistical software package using completely randomized design to compare between the soya protein sources. The treatments were the main effects. The pens were the experimental units for all analysis but for apparent ileal digestibility each pig was the experimental unit. When significant differences were noted, the means were compared using LSD's multiple range test. The level of significance was accepted at $\mathrm{P}<0.05$, unless otherwise noted.

\section{RESULTS}

\section{Chemical composition of fermented soya protein sources and mixed diets}

The crude protein and essential amino acid (EAA) profile of each soya protein sources used is presented in Table 2. The TEAA/CP ratio almost remained similar for FSP-A, FSP-B and SBM. The tryptophan was not determined in any of the protein source.

The analysed composition of the mixed diets is presented in Table 3.

Table 2. Crude protein and essential amino acid profiles of fermented protein sources (as-fed basis) ${ }^{1}$

\begin{tabular}{lccc}
\hline Protein sources $^{2}$ & SBM & FSP-A & FSP-B \\
\hline Crude protein, \% & 45.19 & 53.01 & 57.01 \\
Essential amino acids, \% & & & \\
$\quad$ arginine & 3.27 & 3.97 & 3.83 \\
$\quad$ histidine & 1.34 & 1.44 & 1.68 \\
$\quad$ isoleucine & 1.85 & 2.47 & 2.42 \\
leucine & 4.69 & 4.12 & 5.28 \\
lysine & 2.87 & 3.32 & 3.02 \\
phenylalanine & 2.00 & 2.73 & 2.79 \\
threonine & 1.73 & 2.09 & 2.06 \\
$\quad$ valine & 1.86 & 2.57 & 2.48 \\
methionine & 0.48 & 0.75 & 0.80 \\
total & 20.09 & 23.46 & 24.36 \\
TEAA $^{3 / C P}$ & 0.44 & 0.44 & 0.43 \\
\hline
\end{tabular}

${ }^{1}$ tryptophan was not determined

${ }^{2}$ SBM: soyabean meal; FSP-A: fermented soyabean protein-A; FSP-B: fermented soyabean protein-B

3 total essential amino acid 
Table 3. Analysed nutrient content of diets (as-fed basis) ${ }^{1}$

\begin{tabular}{lcrrrrr}
\hline \multirow{2}{*}{ Item, unit } & \multirow{2}{*}{ Control } & \multicolumn{2}{c}{ FSP-A, \% } & & \multicolumn{2}{c}{ FSP-B, \% } \\
\cline { 3 - 4 } \cline { 6 - 7 } & & \multicolumn{1}{c}{3} & 6.98 & & & \multicolumn{1}{c}{3} \\
\hline Moisture, \% & 6.98 & 6.52 & & 7.08 & 7.16 \\
GE, MJ/kg & 19.76 & 19.64 & 19.78 & & 19.72 & 19.84 \\
Crude protein, \% & 21.25 & 21.53 & 21.62 & & 21.88 & 22.17 \\
Ether extract, \% & 4.38 & 4.07 & 3.93 & & 4.41 & 4.07 \\
Ash, \% & 7.48 & 7.45 & 7.68 & & 7.48 & 7.61 \\
Ca, \% & 0.90 & 0.85 & 0.87 & & 0.84 & 0.85 \\
P, \% & 0.74 & 0.71 & 0.71 & & 0.75 & 0.72 \\
\hline
\end{tabular}

${ }^{1}$ each assay performed in triplicate

\section{Growth performance}

The average daily gain (ADG) was not different in the pigs fed SBM as compared with fermented soya protein sources at 0-14 d measurement (Table 4). At $15-35 \mathrm{~d}$, the ADG was higher $(\mathrm{P}<0.01)$ in the pigs fed FSP-B than to FSP-A but there were no differences at 3 and $6 \%$ level irrespective of the sources. Similar trend of higher $(\mathrm{P}<0.001)$ ADG in FSP-B than FSP-A followed at the overall $(0-35 \mathrm{~d})$ study and it was higher $(\mathrm{P}<0.01)$ at higher level of supplementation $(6 \%)$ than to lower level (3\%). The ADG was higher in FSP-A and FSP-B than

Table 4. Effects of fermented soya protein by different microbes on growth performance in weaned pigs

\begin{tabular}{|c|c|c|c|c|c|c|c|c|}
\hline \multirow{2}{*}{ Item } & \multirow{2}{*}{ Control } & \multicolumn{2}{|c|}{ FSP-A, $\%$} & \multicolumn{2}{|c|}{ FSP-B, \% } & \multirow{2}{*}{ SEM $^{1}$} & \multicolumn{2}{|c|}{ Probability $^{2}(\mathrm{P}<)$} \\
\hline & & 3 & 6 & 3 & 6 & & microbe & level \\
\hline \multicolumn{9}{|l|}{ Day 0 14 } \\
\hline ADG, $\mathrm{g}$ & 269 & 284 & 297 & 295 & 293 & 3.22 & $\mathrm{NS}^{3}$ & NS \\
\hline ADFI, $g$ & 405 & 411 & 435 & 432 & 426 & 4.12 & NS & NS \\
\hline $\mathrm{F} / \mathrm{G}$ & 1.50 & 1.45 & 1.46 & 1.47 & 1.45 & 0.01 & NS & NS \\
\hline \multicolumn{9}{|l|}{ Day $15 \sim 35$} \\
\hline ADG, $\mathrm{g}$ & $428^{c}$ & $438^{\mathrm{bc}}$ & $444^{\mathrm{bc}}$ & $451^{\mathrm{ab}}$ & $463^{\mathrm{a}}$ & 3.67 & $* * 4$ & NS \\
\hline ADFI, $g$ & $674^{b}$ & $673^{b}$ & $675^{\mathrm{b}}$ & $685^{\mathrm{ab}}$ & $688^{a}$ & 2.23 & $*$ & NS \\
\hline $\mathrm{F} / \mathrm{G}$ & 1.57 & 1.54 & 1.52 & 1.52 & 1.49 & 0.01 & NS & NS \\
\hline \multicolumn{9}{|c|}{ Overall (day 0 35) } \\
\hline ADG, $g$ & $365^{\mathrm{d}}$ & $376^{\mathrm{c}}$ & $385^{\mathrm{b}}$ & $389^{\mathrm{ab}}$ & $395^{\mathrm{a}}$ & 2.99 & $* * *$ & $* *$ \\
\hline ADFI, $g$ & $566^{\mathrm{b}}$ & $568^{\mathrm{b}}$ & $579^{\mathrm{a}}$ & $584^{\mathrm{a}}$ & $583^{\mathrm{a}}$ & 2.24 & $* *$ & NS \\
\hline $\mathrm{F} / \mathrm{G}$ & $1.55^{\mathrm{a}}$ & $1.51^{\mathrm{b}}$ & $1.50^{\mathrm{bc}}$ & $1.50^{\mathrm{bc}}$ & $1.48^{\mathrm{c}}$ & 0.01 & NS & NS \\
\hline
\end{tabular}

a,b,c,d values with different superscripts in the same row differ significantly $(\mathrm{P}<0.05)$

${ }^{1}$ pooled standard error of means

2 microbe: A. oryzae vs A. oryzae + B. subtilis; level: 3 vs $6 \%$

${ }^{3}$ not significant $(\mathrm{P}>0.05)$

$4 * \mathrm{P}<0.05 ; * * \mathrm{P}<0.01 ; * * * \mathrm{P}<0.001$ 
the SBM fed group at both phases when mean comparison was done. The feed to gain ratio was not different among FSP-A and FSP-B diets when the microbe effect or level effect was carried out.

\section{Apparent nutrient digestibility}

The apparent nutrient digestibility studies conducted after 14 days of experimental feeding is presented in Table 5 . The digestibility of crude protein, ether extract, calcium and phosphorus was higher $(\mathrm{P}<0.05)$ in FSP-B fed diets than in SBM and FSP-A. There were no differences in apparent nutrient digestibility when the two levels were compared irrespective of source.

Table 5. Effects of fermented soya protein by different microbes on apparent nutrient digestibility in weaned pigs (at day 14)

\begin{tabular}{|c|c|c|c|c|c|c|c|c|}
\hline \multirow{2}{*}{ Item, unit } & \multirow{2}{*}{ Control } & \multicolumn{2}{|c|}{ FSP-A, $\%$} & \multicolumn{2}{|c|}{ FSP-B, $\%$} & \multirow{2}{*}{ SEM $^{1}$} & \multicolumn{2}{|c|}{ Probability $^{2}(\mathrm{P}<)$} \\
\hline & & 3 & 6 & 3 & 6 & & microbe & level \\
\hline$\overline{\mathrm{DM}}, \%$ & 82.18 & 83.80 & 84.29 & 85.28 & 84.33 & 0.36 & $\mathrm{NS}^{3}$ & NS \\
\hline GE, \% & 82.29 & 83.05 & 83.69 & 84.85 & 84.64 & 0.37 & NS & NS \\
\hline Crude protein, $\%$ & $73.61^{\mathrm{d}}$ & $77.21^{\mathrm{c}}$ & $77.82^{\mathrm{bc}}$ & $79.16^{\mathrm{ab}}$ & $79.75^{\mathrm{a}}$ & 0.62 & $* * 4$ & NS \\
\hline Ether extract, \% & $63.64^{\mathrm{b}}$ & $68.70^{\mathrm{a}}$ & $65.69^{\mathrm{b}}$ & $70.35^{\mathrm{a}}$ & $70.37^{\mathrm{a}}$ & 0.77 & $* *$ & NS \\
\hline Ash, $\%$ & 52.97 & 59.35 & 60.26 & 61.31 & 60.06 & 0.90 & NS & NS \\
\hline $\mathrm{Ca}, \%$ & $56.94^{\mathrm{b}}$ & $58.08^{\mathrm{b}}$ & $57.03^{\mathrm{b}}$ & $60.63^{\mathrm{a}}$ & $60.74^{\mathrm{a}}$ & 0.54 & $* *$ & NS \\
\hline $\mathrm{P}, \%$ & $48.26^{c}$ & $52.77^{\mathrm{b}}$ & $53.81^{\mathrm{b}}$ & $56.90^{\mathrm{a}}$ & $53.58^{\mathrm{b}}$ & 0.81 & $*$ & NS \\
\hline
\end{tabular}

a,b,c,d values with different superscripts in the same row differ significantly $(\mathrm{P}<0.05)$

${ }^{1}$ pooled standard error of means

2 microbe : A. oryzae vs A. oryzae + B. subtilis; level: 3 vs $6 \%$

${ }^{3}$ not significant $(\mathrm{P}>0.05)$

$4 * \mathrm{P}<0.05 ; * * \mathrm{P}<0.01$

\section{Apparent ileal amino acid digestibilities}

The sub-mean of apparent ileal digestibility of essential amino acids was not different in FSP-A and FSP-B diets (Table 6). The apparent ileal digestibility of only Leu was higher $(\mathrm{P}<0.05)$ in FSP-B than FSP-A. But the digestibility of His, Met, Thr, Val, and Cys was higher $(\mathrm{P}<0.05)$ at higher level of supplementation than the lower level. The sub-mean apparent digestibility of EAA and non-EAA were comparable between FSP-A and FSP-B but was higher $(\mathrm{P}<0.05)$ at higher level. 
Table 6. Effects of fermented soya protein by different microbes on apparent ileal digestibility of amino acids in weaned pigs

\begin{tabular}{|c|c|c|c|c|c|c|c|c|}
\hline \multirow[t]{2}{*}{ Item } & \multirow[t]{2}{*}{ Control } & \multicolumn{2}{|c|}{ FSP-A, $\%$} & \multicolumn{2}{|c|}{ FSP-B, $\%$} & \multirow[t]{2}{*}{$\mathrm{SEM}^{1}$} & \multicolumn{2}{|c|}{ Probability $^{2}(\mathrm{P}<)$} \\
\hline & & 3 & 6 & 3 & 6 & & microbe & level \\
\hline \multicolumn{9}{|c|}{ Essential amino acids, \% } \\
\hline Arg & 78.78 & 80.91 & 82.05 & 82.71 & 81.81 & 0.49 & $\mathrm{NS}^{3}$ & NS \\
\hline His & $71.59^{\mathrm{c}}$ & $72.50^{\mathrm{bc}}$ & $75.42^{\mathrm{ab}}$ & $72.01^{\mathrm{c}}$ & $76.93^{\mathrm{a}}$ & 0.68 & NS & $* * 4$ \\
\hline Ile & 74.66 & 75.18 & 76.65 & 76.23 & 78.56 & 0.57 & NS & NS \\
\hline Leu & $76.08^{\mathrm{c}}$ & $77.26^{\mathrm{bc}}$ & $78.15^{\mathrm{abc}}$ & $79.4^{\mathrm{ab}}$ & $79.94^{\mathrm{a}}$ & 0.48 & $*$ & NS \\
\hline Lys & 74.76 & 76.47 & 78.59 & 78.37 & 77.56 & 0.56 & NS & NS \\
\hline Met & $77.21^{\mathrm{c}}$ & $79.17^{\mathrm{bc}}$ & $81.94^{\mathrm{ab}}$ & $79.03^{c}$ & $82.66^{\mathrm{a}}$ & 0.64 & NS & $* *$ \\
\hline Phe & 74.43 & 76.60 & 77.00 & 75.09 & 79.15 & 0.59 & NS & NS \\
\hline Thr & $66.30^{\mathrm{c}}$ & $68.21^{\mathrm{bc}}$ & $71.23^{\mathrm{ab}}$ & $69.49^{\mathrm{bc}}$ & $73.14^{\mathrm{a}}$ & 0.75 & NS & $*$ \\
\hline Val & $72.89^{\mathrm{c}}$ & $74.70^{\mathrm{bc}}$ & $77.55^{\mathrm{ab}}$ & $76.34^{\mathrm{ab}}$ & $78.64^{\mathrm{a}}$ & 0.67 & NS & * \\
\hline Sub-mean & $74.08^{\mathrm{c}}$ & $75.67^{\mathrm{bc}}$ & $77.62^{\mathrm{ab}}$ & $76.52^{\mathrm{ab}}$ & $78.71^{\mathrm{a}}$ & 0.51 & NS & $*$ \\
\hline \multicolumn{9}{|c|}{ Non-essential amino acids, $\%$} \\
\hline Ala & 72.34 & 74.84 & 77.10 & 75.44 & 76.74 & 0.62 & NS & NS \\
\hline Asp & 73.34 & 74.77 & 77.02 & 75.62 & 77.23 & 0.53 & NS & NS \\
\hline Cys & $57.34^{\mathrm{c}}$ & $61.33^{\mathrm{b}}$ & $64.12^{\mathrm{ab}}$ & $61.59^{b}$ & $65.90^{\mathrm{a}}$ & 0.90 & NS & $*$ \\
\hline Glu & 73.29 & 77.96 & 80.52 & 79.10 & 79.35 & 1.03 & NS & NS \\
\hline Gly & 58.16 & 60.19 & 62.63 & 62.91 & 64.16 & 0.96 & NS & NS \\
\hline Ser & 70.46 & 73.71 & 75.48 & 74.10 & 77.37 & 0.76 & NS & NS \\
\hline Sub-mean & $67.49^{c}$ & $70.46^{\mathrm{b}}$ & $72.81^{\mathrm{ab}}$ & $71.46^{\mathrm{ab}}$ & $73.46^{\mathrm{a}}$ & 0.66 & NS & $*$ \\
\hline Total & $70.78^{\mathrm{c}}$ & $73.07^{\mathrm{b}}$ & $75.22^{\mathrm{ab}}$ & $73.99^{\mathrm{ab}}$ & $76.08^{\mathrm{a}}$ & 0.56 & NS & * \\
\hline
\end{tabular}

abc values with different superscripts in the same row differ significantly $(\mathrm{P}<0.05)$

${ }^{1}$ pooled standard error of means

${ }^{2}$ microbe: A. oryzae vs A. oryzae + B. subtilis; level: 3 vs $6 \%$

${ }^{3}$ not significant $(\mathrm{P}>0.05)$

$4 * \mathrm{P}<0.05 ; * * \mathrm{P}<0.01$

\section{Effect on villous height and crypt depth}

The dietary protein sources had not an impact on villous height at the ileum (Table 7). The crypt depth and the villous height to crypt depth ratio were not affected by dietary treatments.

TABLE 7. Effects of fermented soya protein by different microbes on ileal villous height, crypt depth and villous height: crypt depth ratio in weaned pigs

\begin{tabular}{|c|c|c|c|c|c|c|c|c|}
\hline \multirow{2}{*}{ Item } & \multirow{2}{*}{ Control } & \multicolumn{2}{|c|}{ FSP-A, $\%$} & \multicolumn{2}{|c|}{ FSP-B, $\%$} & \multirow{2}{*}{ SEM $^{1}$} & \multicolumn{2}{|c|}{ Probability $^{2}(\mathrm{P}<)$} \\
\hline & & 3 & 6 & 3 & 6 & & microbe & level \\
\hline Villous height, $\mu \mathrm{m}$ & 329 & 335 & 337 & 346 & 340 & 5.08 & $\mathrm{NS}^{3}$ & NS \\
\hline Crypt depth, $\mu \mathrm{m}$ & 215 & 222 & 216 & 211 & 213 & 3.52 & NS & NS \\
\hline Villous height: crypt depth & 1.54 & 1.51 & 1.57 & 1.65 & 1.61 & 0.03 & NS & NS \\
\hline
\end{tabular}

${ }_{1}^{1}$ pooled standard error of means

${ }^{2}$ microbe: $A$. oryzae vs $A$. oryzae $+B$. subtilis; level: 3 vs $6 \%$

${ }^{3}$ not significant $(\mathrm{P}>0.05)$ 


\section{DISCUSSION}

The CP content was higher in FSP-B (57.01\%) and the lowest in SBM (45.19\%). The analysed amino acid composition of fermented soya proteins for EAA is nearly similar to SBM but the CP content is higher in FSP-A and FSP$B$ than in SBM. The higher CP content in FSP could be because of increased microbial content after fermentation.

The higher ADG in FSP-B could be the effect of higher $(\mathrm{P}<0.05)$ average daily feed intake (ADFI) when compared with FSP-A. A linear increase in ADFI because of feeding processed soya proteins was also reported by Min et al. (2004). The findings in the present study once again confirmed that FSP could significantly improve the ADG than SBM fed group that we reported earlier (Yun et al., 2005). The reason for lower ADG could be poor palatability; one of the distinct problems with SBM-based diets as mentioned by Sohn et al. (1994). Although the palatability problem was not more prominently observed in the present research, but similar response of lower feed intake and ADG in SBM fed diet when compared with dried skim milk (DSM), ISP (isolated soya proteins), SDPP and wheat gluten fed diets were also noted by Chae et al. (1999). It could be considered that the anti-nutritional factors in SBM that normally hinders performance was less effective in FSP-B fed group than FSP-A since fermentation removed such antigenic components. There are few studies (Min et al., 2004; Yun et al., 2005), where fermented soyabean proteins could serve as an alternative protein source in early-weaned pigs. The trypsin inhibitor, oligosaccharides like raffinose and stachyose in soyabean meal was removed during fungal and bacterial fermentation by protease and glucoamylase causing hydrolysis (Kim, 2005). The improvement in performance by FSP feeding could be the reduction in anti-nutritional factors, increase in CP content and the processed soya products contained small peptides that could be easily hydrolysed by digestive proteases. We measured the molecular weight of peptides in FSP by gel electrophoresis and compared with other commercial processed soya sources (data not shown). Min et al. (2004) also reported that feeding processed soya protein to weanling pigs that has high proportion of small peptides increased growth performance.

The higher apparent nutrient digestibility in FSP-B group might have culminated into increased weight gains in these animals. The apparent digestibility of nutrients was lowest in SBM than others. It is commonly noticed that when the feed intake is low, the nutrient digestibility is high but we could not find such effect in SBM fed animals. Even the digestibility of GE, CP, EE, calcium and phosphorus were lower in SBM fed animals as compared with other plant protein sources (FSP and rice protein concentrate) in our earlier studies (Yun et al., 2005). The lower nutrient digestibility in SBM than that of milk products based diets 
was also reported previously (Walker et al., 1986; Sohn et al., 1994). The poor digestibility of nutrients in pigs fed the SBM diet may be due to the presence of indigestible carbohydrate complexes (Walker et al., 1986), indigestible proteins such as glycinin and $\beta$-conglycinin (Li et al., 1991a), and (or) anti-nutritional factors, in addition to the incomplete development of digestive system in pigs. The lower apparent digestibility of nutrients lowered the ADG in this group. Higher DM and $\mathrm{N}$ digestibilities were also reported in pigs fed processed soya protein diet than to negative control (without processed soya protein) by Min et al. (2004). As previously discussed, the FSP contained smaller peptides that could be easily digested by digestive proteases and this could be the reason that the CP digestibility was improved in FSP fed pigs.

The mean apparent ileal digestibility of non-essential amino acids was not different between FSP-A and FSP-B. The total amino acid digestibility also revealed the similar trend. The digestibility of some of the essential amino acids along with Leu was lower in SBM group than other plant protein sources like FSP and rice protein concentrate was reported earlier (Yun et al., 2005). The sub-mean digestibility of essential amino acids in an isolated soya protein based diet was not greater than that of mean digestibility of essential amino acid in a SBM based diet was reported by Chae et al. (1999), that supported the present study. But the ileal digestibilities of amino acids in refined soyabean proteins such as isolated soya protein and soya protein concentrate were improved over that of soyabean meal due to reduction in anti-nutritional factors was reported by Walker et al. (1986) and Sohn et al. (1994) that contradicts our findings. Feeding processed soya protein to weanling pigs had increased apparent ileal digestibilities of most amino acids was earlier reported (Min et al., 2004).

Hypersensitivity to antigens in diet may be responsible for the morphological changes in intestine was suggested by Li et al. (1990), but the present study failed to show any such changes. High levels of plant proteins that may contain strong antigens greatly affect villous height and gut morphology (Li et al., 1991b). Kelly et al. (1991) and Vente-Spreeuwenberg et al. (2004) reported that villous height and crypt depth were positively related to feed intake. Although the differences in feed intake in the present study were significant, but failed to contribute for significant changes in the villous structures. Also there are reports that mentioned feeding high concentrations of soyabean meal ( $44.43 \%$ of diet) to the pig postweaning has a detrimental effect on the small intestine, but this effect was minimized when soyabean meal (31.90\% of diet) was fed as part of a maize-based diet (Dunsford et al., 1989). We fed high quality soyabean meal to the extent of only $15 \%$ and this may not have any untoward effects on small intestine. Kelly et al. (1991) and Pluske et al. (1996) reported that pigs fed less feed showed villous atrophy and increased crypt depth at all sites along the small intestine compared 
with pigs fed a higher quantity feed. The findings in our study are contradictory to the reports mentioned above and possibly this could be because of not much numerical differences in feed intake among treatments, although it is significant.

\section{CONCLUSIONS}

The present study was conducted to see the effects of fungal and bacterial fermented soya proteins on the growth performance, apparent nutrient digestibilities and ileal histometry of weanling pigs. The findings of the present study showed that the fermented soya proteins could be used as a replacement to soyabean meal and may be an alternative for costly processed soya protein sources.

\section{REFERENCES}

AOAC, 1990. Official Method of Analysis, Association of Official Analytical Chemists. $15^{\text {th }}$ Edition. Arlington, VA

Cera K.R., Mahan D.C., Cross R.F., Reinhart G.A., Whitmoyer R.E., 1988. Effect of age, weaning and post weaning diet on small intestinal growth and jejunal morphology in young swine. J. Anim. Sci. 66, 574-584

Chae B.J., Han In K., Kim J.H., Yang C.J., Hancock J.D., Kim I.H., Anderson D.A., 1999. Effects of dietary protein sources on ileal digestibility and growth performance for early-weaned pigs. Livest. Prod. Sci. 58, 45-54

Dunsford B.R., Knabe D.A., Haensly W.E., 1989. Effect of dietary soybean meal on the microscopic anatomy of the small intestine in the early-weaned pig. J. Anim. Sci. 67, 1855-1863

Fenton T.W., Fenton M., 1979. An improved method for chromic oxide determination in feed and feces. Can. J. Anim. Sci. 59, 631-634

Genebiotech, 2004. Pepsoygens, a Fermented Soybean Product for Pigs. Product Brochure Information. Genebiotech Co. Ltd. Seoul (Korea)

Kelly D., Smyth J.A., McCracken K.J., 1991. Digestive development in the early weaned pig. I. Effect of continuous nutrient supply on the development of the digestive tract and on changes in the digestive enzyme activity during the first week post-weaning. Brit. J. Nutr. 65, 169-180

Kim Y.G., 2005. Effects of feeding fermented soy protein on growth performance, nutrients digestibility, intestinal morphology and immune response in weaned pigs. Ph.D. Thesis submitted to Kangwon National University, Chunchon (Republic of Korea)

Lalles J.P., 1993. Soy products as protein sources for preruminant and young pigs. In: J.K. Drackley (Editor). Soy in Animal Nutrition. Federation of Animal Science Society. Savoy, IL, pp. 106125

Li D.F., Nelssen J.L., Reddy P.G., Blecha F., Hancock J.D., Allee G.L., Goodband R.D., Klemm R.D., 1990. Transient hypersensitivity to soybean meal in the early-weaned pig. J. Anim. Sci. 68, 1790-1799

Li D.F., Nelssen J.L., Reddy P.G., Blecha F., Klemm R.D., Giesting D.W., Hancock J.D., Allee G.L., Goodband R.D., 1991a. Measuring suitability of soybean products for early-weaned pigs with immunological criteria. J. Anim. Sci. 69, 3299-3307 
Li D.F., Nelssen J.L., Reddy P.G., Blecha F., Klemm R.D., Goodband R.D., 1991b. Inter-relationship between hypersensitivity to soybean proteins and growth performance in early-weaned pigs. J. Anim. Sci. 69, 4062-4069

Min B.J., Hong J.W., Kwon O.S., Lee W.B., Kim Y.C., Kim I.H., Cho W.T., Kim J.H., 2004. The effect of feeding processed soy protein on the growth performance and apparent ileal digestibility in weanling pigs. Asian-Austr. J. Anim. Sci. 17, 1271-1276

Moore S., 1963. On the determination of cystine as cysteric acid. J. Biol. Sci. 38, 235-237

NRC, 1998. Nutrient Requirements of Swine. 10 $0^{\text {th }}$ Edition. National Academy Press, Washington, DC

Pluske J.R., Williams I.H., Aherne F.X., 1996. Villous height and crypt depth in piglets in response to increases in the intake of cow's milk after weaning. Anim. Sci. 62, 145-158

SAS, 1985. SAS User's Guide: Statistics, SAS Inst. Inc. Cary, NC

Sohn K.S., Maxwell C.V., Buchanan D.S., Southern L.L., 1994. Improved soybean protein sources for early-weaned pigs: I. Effects on performance and total track amino acid digestibility. J. Anim. Sci. 72, 622-630

Vente-Spreeuwenberg M.A.M., Verdonk J.M.A.J., Koninkx J.F.J.G., Beynen A.C., Verstegen M.W.A., 2004. Dietary protein hydrolysates vs. the intact proteins do not enhance mucosal integrity and growth performance in weaned piglets. Livest. Prod. Sci. 85, 151-164

Walker W.R., Maxwell C.V., Owens F.N., Buchanan D.S., 1986. Milk versus soybean protein sources for pigs: I. Effects of performance and digestibility. J. Anim. Sci. 63, 505-512

Yun J.H., Kwon I.K., Lohakare J.D., Choi J.Y., Yong J.S., Zheng J., Cho W.T., Chae B.J., 2005. Comparative efficacy of plant and animal protein sources on the growth performance, nutrient digestibility, morphology and caecal microbiology of the early-weaned pigs. Asian-Austr. J. Anim. Sci. 18, 1285-1293 